\title{
PELATIHAN BERWIRAUSAHA EDIT VIDEO SHOOTING DAN EVENT ORGANIZER BAGI TENAGA KERJA INDONESIA (TKI) PURNA DI SUKABUMI JAWA BARAT
}

\author{
Dr. Dedi Purwana ES, Suparno, Agus Wibowo \\ dpurwana@unj.ac.id \\ Prodi Pendidikan Ekonomi, Fakultas Ekonomi, Universitas Negeri Jakarta
}

\begin{abstract}
ABSTRAK
Kegiatan Pelatihan berwirausaha Edit video Shooting dan Event Organizer Bagi Tenaga Kerja Indonesia (TKI) purna Di Sukabumi Jawa Barat, bertujuan: (1) Untuk melatih para TKI Purna memiliki kemampuan literasi keuangan sebagai modal berwirausaha; (2) Untuk melatih para TKI Purna berwirausaha membuka jasa editing video shooting, dan (3) Untuk melatih para TKI Purna berwirausaha dengan menjadi pelaku event organizer.

Khalayak sasaran dari kegiatan ini adalah para TKI Purna di Kabupaten Sukabumi Jawa Barat, khususnya di Desa di Desa Cibolang, Kecamatan Gunung Guruh, Kabupaten Sukabumi Jawa Barat sejumlah 25 orang.

Kegiatan ini dilakukan dalam dua materi penting yang sangat terkait dengan pelatihan berwirausaha TKI Purna, yaitu Edit Video Shooting dan Even Organizer. Kegiatan ini dilakukan selama satu hari, yaitu tanggal 20 Agustus 2016. Pada tahap pertama diberikan materi Edit Video Shooting, agar para TKI Purna bisa membuka jasa di bidang tersebut. Selanjutnya pada tahap kedua diberikan materi keterampilan even organizer agar para TKI Purna bisa membuka usaha di bidang tersebut.

Berdasarkan hasil pelatihan yang sudah dilakukan didapat beberapa kesimpulan di antaranya: (1) Para TKI Purna sudah memiliki kemampuan literasi keuangan sebagai modal berwirausaha; (2) Para TKI Purna sudah memiliki kemampuan edit video shooting sebagai bekal berwirausaha di bidang tersebut, dan (3) Para TKI Purna sudah memiliki kemampuan even organizer sebagai bekal untuk berwirausaha di bidang tersebut.
\end{abstract}

Kata Kunci: Pelatihan Berwirausaha, TKI Purna

\section{PENDAHULUAN}

A. ANALISA SITUASI

Indonesia merupakan pemasok tenaga kerja (TKI) terbanyak ke luar negeri. Menurut data Badan Nasional Penempatan dan Perlindungan Tenaga Kerja Indonesia (BNP2TKI, 2015) sebanyak 429.872 orang menjadi TKI. Jumlah itu meliputi 219.610 orang (58 persen) TKI formal dan 182.262 orang (42 persen) TKI informal. Data terbaru dirilis BNP2TKI (2015) menyebutkan sepanjang 20142015 Jawa Barat merupakan provinsi tertinggi dari 33 provinsi di Indonesia yang mengirim TKI ke luar negeri dengan jumlah mencapai 105,479 orang.

Berdasarkan data BNP2TKI (2015) juga diketahui bahwa di Jawa Barat terdapat sembilan kabupaten/Kota yang menjadi daerah pemasok TKI terbanyak. Kesembilan daerah itu yakni
Kabupaten Indramayu, Cirebon, Majalengka, Bandung, Sukabumi, Cianjur, Karawang, Purwakarta, dan Subang. Namun, dari sembilan kabupaten di Jawa Barat tersebut, TKI dari daerah Kabupaten Sukabumi memiliki karakteristik tersendiri. Bisa dibilang, TKI sangat lekat bagi Kabupaten Sukabumi. Jumlah penduduk Kabupaten Sukabumi sekitar 2,4 juta orang, di mana angkatan kerja sekitat 793 ribu orang namun yang bekerja hanya 739 ribu. Ada kurang lebih 300 ribu orang yang menjadi pengangguran. Dengan keterbatasan peluang kerja di dalam negeri tersebut, wajar jika penduduk Kabupaten Sukabumi banyak memilih bekerja ke luar negeri.

Selain itu, para TKI dianggap sebagai pahlawan daerah, karena menyumbang dana yang tidak sedikit. Berdasarkan data PT Pos Indonesia, 
selama 2015 uang dari luar negeri yang dikirim ke Kabupaten Sukabumi mencapai lebih dari RP 700 miliar. Singkatnya, berdasarkan laporan PT Pos Indonesia (2015), hampir 90 persen pengirim uang luar negeri ke Indonesia di donimasi TKI asal Sukabumi.

Sayangnya, meski TKI dari daerah Sukabumi menjadi pahlawan devisa, namun perlakuan terhadap mereka masih jauh dari penghargaan. Mantan TKI atau TKI Purna yang sudah kembali Sukabumi juga masih belum tentu terjamin kesejahteraannya. Itulah sebabnya, para TKI asal Sukabumi memilih kembali merantau ke luar negeri meski harus menempuh risiko yang tidak ringan. Selain itu, tingginya jumlah warga asal Kabupaten Sukabumi yang menjadi TKI, tidak disertai pengelolaan keuangan hasil saat bekerja di luar negeri. Sehingga tidak jarang para mantan TKI yang sudah bekerja di luar negeri ketika pulang ke kampung halamannya tidak memiliki apapun.

Berdasarkan uraian-uraian di atas dapat disimpulkan bahwa mendesak dilakukan pelatihan berwirausaha kepada para TKI Purna di Kabupaten Sukabumi. Kegiatan ini selain bertujuan membekali para TKI Purna dengan keterampilan dan kecakapan hidup (liveskills), juga sejalan dengan harapan pemangku kepentingan lokal di Kabupaten Sukabumi, khususnya Kepala Disnakertrans Kabupaten Sukabumi, serta sejalan dengan progran pemerintah melalui BNP2TKI. Data dan fakta sebagaimana diuraikan, menjadi dasar bagi kami untuk menyusun proposal pengabdian masyarakat dengan judul: "Pelatihan Berwirausaha Edit Video Shooting Dan Event Organizer Bagi Tenaga Kerja Indonesia Purna Di Kabupaten Sukabumi."

\section{B. PERUMUSAN MASALAH}

Berdasarkan analisis situasi sebagaimana telah diuraikan di atas, maka membekali TKI Purna di Kabupaten Sukabumi dengan keterampilan berwirausaha merupakan solusi tepat. Pelatihan kewirausahaan ini menjadi penting, bukan saja agar para TKI Purna tersebut memiliki keterampilan atau kecakapan hidup (lifeskills). Akan tetapi, diharapkan selepas pelatihan tersebut para TKI Purna dapat memulai berwirausaha, menggeluti usaha tersebut, dan mereka tidak tertarik lagi untuk kembali menjadi TKI. Pelatihan berwirausaha edit video shooting dan event organizer dipilih dengan asumsi bahwa para TKI Purna sudah memiliki kemampuan di bidang teknologi/IT yang lebih.

\section{TUJUAN KEGIATAN}

Tujuan dari kegiatan pengabdian masyarakat ini adalah: (1) Untuk melatih para TKI Purna memiliki kemampuan literasi keuangan sebagai modal berwirausaha; (2) Untuk melatih para TKI Purna berwirausaha membuka jasa editing video shooting, dan (3) Untuk melatih para TKI Purna berwirausaha dengan menjadi pelaku event organizer.

\section{MANFAAT KEGIATAN}

Adapun manfaat dari kegiatan pengabdian masyarakat ini adalah: (1) Para TKI Purna memiliki kemampuan literasi keuangan sebagai bekal mereka berwirausaha; (2) Para TKI Purna terampil mengoperasikan program editing video shooting dan mampu membuka usaha di bidang tersebut; (3) Para TKI Purna mampu menjadi pelaku sekaligus membuka usaha di bidang event organizer, dan (4) Terbinanya hubungan yang baik antara para TKI Purna dan Stakeholder di Kabupaten Sukabumi Jawa Barat dengan Universitas Negeri Jakarta.

\section{METODE PELAKSANAAN \\ A. METODE KEGIATAN}

Metode kegiatan Pelatihan Berwirausaha Edit Video Shooting Dan Event Organizer Bagi TKI Purna di Desa Cibolang, Kecamatan Gunung Guruh, Kabupaten Sukabumi Jawa Barat ini berupa pelatihan dan workshop. Dengan metode tersebut diharapkan para peserta tidak hanya belajar teori mempraktekan langsung bagaimana mengedit video hasil shooting mereka, serta menjadi pelaku event organizer.

\section{B. KHALAYAK SASARAN (PESERTA)}

Pelaksanaan kegiatan Pelatihan Berwirausaha Edit Video Shooting dan Event Organizer Bagi TKI Purna ini dilaksanakan di Kabupaten Sukabumi Jawa Barat. Adapun lokasi yang dipilih terletak di Balai Desa Cibolang, Kecamatan Gunung Guruh, Kabupaten Sukabumi. 
Lokasi Desa Cibolang, Kecamatan Gunung Guruh, Kabupaten Sukabumi dipilih karena berdasarkan data dari BNP2TKI (2014), diketahui bahwa di Desa ini banyak warganya yang menjadi TKI, dan sudah ada yang menjadi TKI Purna. Adapun tempat mereka bekerja sebagian besar di Timur Tengah, khususnya Arab Saudi. Peserta kegiatan Pelatihan Berwirausaha Edit Video Shooting dan Event Organizer Bagi TKI Purna ini sebanyak 25 orang warga desa Cibolang, yang merupakan TKI Purna.

\section{A. TEMPAT KEGIATAN}

Kegiatan Pelatihan Berwirausaha Edit Video Shooting Dan Event Organizer ini bertempat di Balai Desa Cibolang, Kecamatan Gunung Guruh, Kabupaten Sukabumi.

\section{B. JADWAL PELAKSANAAN}

Kegiatan Pelatihan Berwirausaha Edit Video Shooting Dan Event Organizer, dalam rangka pengabdian masyarakat ini telah dilaksanakan pada hari Sabtu, 20 Agustus 2016, Pukul 08.30 s/d 16.15 .

\section{TINJAUAN PUSTAKA}

\section{A. TENAGA KERJA INDONESIA PURNA}

Tenaga Kerja Indonesia (TKI) adalah sebutan bagi warga negara Indonesia yang bekerja di luar negeri (seperti Malaysia, Timur Tengah, Hongkong, Taiwan, Korea, Australia dan Amerika Serikat) dalam hubungan kerja untuk jangka waktu tertentu dengan menerima upah. Adapun yang dimaksud dengan TKI Purna adalah TKI yang telah habis kontrak kerjanya dan telah kembali ke Indonesia, serta kembali ke daerah asal. Terkait TKI Purna ini, Nusron Wahid (2015) memberikan batasan bahwa TKI Purna ini TKI yang telah menyelesaikan kontrak kerja minimal selama dua tahun dan tinggal di Indonesia kurang dari satu tahun.

\section{B. KEWIRAUSAHAAN DAN EKONOMI KREATIF}

Wirausaha dapat disebut sebagai pahlawan ekonomi. Mengapa? Karena meski jumlahnya kecil, kontribusi mereka tidak kurang dari $70 \%$ terhadap perekonomian nasional. Selanjutnya entrepreneurship merupakan karakter kombinatif yang merupakan fusi antara sikap kompetitif, visioner, kejujuran, pelayanan, pemberdayaan, pantang menyerah, dan kemandirian. Karakter ini bersatu dan menjadi kebutuhan langsung dalam proses wirausaha. Secara sederhana, entrepreneurship memiliki ciri-ciri swadaya usaha serta mengandung komponen manajemen pemasaran, produksi, dan finansial. Seorang entrepreneur / wirausahawan yang memiliki potensi sukses adalah mereka yang mengerti kegunaan pendidikan untuk menunjang kegiatan serta mau belajar untuk meningkatkan pengetahuan. Lingkungan pendidikan dimanfaatkan oleh entrepreneur sebagai sarana mencapai tujuan. Adapun pendidikan di sini berarti pemahaman suatu masalah yang dilihat dari sudut keilmuan atau teori sebagai landasan berpikir.

Menurut Pinchot (Husaini Usman, 2010), karakter kewirausahaan itu merupakan kemampuan untuk menginternalisasikan bakat, rekayasa, dan peluang yang ada. Sementara, wirausaha adalah orang yang berani mengambil resiko, inovatif, kreatif, pantang menyerah, dan mampu menyiasati peluang secara tepat. Lebih dari itu, karakter kewirausahaan juga sangat urgen dalam menentukan kemajuan perekonomian suatu negara. Bukan hanya ketepatan prediksi dan analisis yang tepat, tetapi juga merangsang terjadinya invensi dan inovasi penemuan-penemuan baru yang lebih efektif bagi pertumbuhan ekonomi.

Menurut Kemendiknas (2010:15-17), kewirausahan adalah suatu sikap, jiwa dan kemampuan untuk menciptakan sesuatu yang baru, yang sangat bernilai dan berguna; baik bagi dirinya sendiri maupun bagi orang lain. Kewirausahaan ini merupakan sikap mental dan jiwa, yang selalu aktif atau kreatif, berdaya, bercipta, berkarya, bersahaja, dan berusaha dalam rangka meningkatkan pendapatan atas kegiatan usahanya. Sementara wirausaha adalah orang yang terampil memanfaatkan peluang dalam mengembangkan usahanya, dengan tujuan untuk meningkatkan kehidupannya.

Menurut Norman M. Scarborough (Kemendiknas, 2010), wirausahawan adalah orang yang memiliki kemampuan melihat dan menilai kesempatan-kesempatan bisnis, mengumpulkan pelbagai sumber daya yang dibutuhkan, untuk mengambil keuntungan dan 
tindakan yang tepat, serta memiliki sifat, watak dan kemauan untuk mewujudkan gagasan inovatif rangka meraih sukses/meningkatkan pendapatan. Inti dari pendapat Norman M. Scarborough dan Thomas W. Zimmerer ini adalah bahwa wirausaha merupakan orang yang memiliki karakter wirausaha, dan mengaplikasikan hakikat kewirausahaan itu dalam hidupnya. Dengan kata lain, wirausaha adalah orang yang memiliki jiwa kreativitas, dan inovatif yang tinggi dalam hidupnya.

Berdasarkan pendapat beberapa ahli tersebut dapat disimpulkan bahwa kewirausahaan merupakan kesatuan terpadu dari semangat nilai-nilai dan prinsip serta sikap, kiat, seni dan tindakan nyata yang sangat perlu, tepat dan unggul dalam menangani dan mengembangkan kegiatan usaha. Batasan kewirausahaan melekat pada orangorang secara pribadi, tetapi sebagian melekat pada kelembagaan. Dengan demikian, pengembangan kewirausahaan tidak hanya menyangkut pribadi perseorangan, tetapi memerlukan wadah, yaitu perusahaan yang ditangani atau dikembangkan.

Beberapa prinsip umum dalam penumbuhan, pengembangan dan penyebarluasan kewirausahaan, yaitu semangat, sikap, perilaku dan kinerja seseorang atau kelompok orang. Kemauan dan kemampuan kewirausahaan yang dipengaruhi oleh faktor keturunan atau bakat, upaya penumbuhan, dan pengembangan. Setiap daerah selalu muncul orang-orang yang mempunyai bakat wirausaha dengan tingkatan yang berbedabeda. Pada intinya semangat sikap dan perilaku kewirausahaan tidak semua orang dapat memiliki, tetapi dengan bekerja keras mau mengambil contoh orang lain tentunya jiwa kewirausahaan berangsur-angsur akan tumbuh dan berkembang (Dedi Purwana, 2011).

Adapun ekonomi kreatif adalah istilah baru yang untuk pertamakali diperkenalkan oleh ekonom John Howkins dalam bukunya The Creative Economy: How People Make Money from Ideas (2001). Tak dinyana, gagasan itu mampu menginspirasi dan mendorong lahirnya aliran baru dalam ekonomi modern. Ekonomi kreatif merupakan konsep yang mengintensifkan informasi dan kreativitas dengan mengandalkan ide dan pengetahuan dari sumberdaya manusia sebagai faktor produksi yang utama. Konsep ini akan efektif jika didukung dengan keberadaan industri kreatif yang menjadi pengejawantahannya.

Sektor ekonomi kreatif dianggap paling menjanjikan dewasa ini. Data yang dirilis PBB setahun lalu menyebutkan bahwa ekonomi kreatif berada pada sektor paling dinamis dalam perekonomian dunia dan menawarkan kesempatan pertumbuhan yang tinggi di negaranegara berkembang. Lebih dari itu, sektor ekonomi kreatif dapat berkontribusi besar pada pertumbuhan ekonomi dan kemakmuran, terutama bagi negara-negara berkembang. Sekitar 30 negara telah meraup keuntungan dari ekonomi kreatif dan lebih dari 100 negara telah memberikan perhatian serius dengan menggunakan aset warisan budaya mereka sebagai modal dalam perekonomian.

\section{a. Edit Video Shooting}

Saat ini dan beberapa tahun ke depan, bisa diprediksi kebutuhan akan editing-video shooting sangat dibutuhkan masyarakat. Jika dilihat dari tarif, serta 1 VCD dengan durasi (rentang waktu) $1 \mathrm{Jam}$, biaya/harga $=$ Rp. 250.000,- per VCD. Biasanya untuk video wedding/perkawinan, ulang tahun, sunat/khitanan, umroh \& haji, wisuda, acara-acara penting lainnya $=2 \mathrm{VCD}=2 \mathrm{VCD}$ x Rp. $250.000,-=$ Rp. 500.000. Tapi bagi usaha yang sudah memiliki brand/nama professional bisa memberikan harga $=2 \mathrm{VCD}=2 \mathrm{VCD} \times \mathrm{Rp}$. $750.000,-=$ Rp. 1.500 .000 .

Adapun peralatan yang dibutuhkan untuk usaha video shooting-editing di antaranya adalah handycam/kamera shooting. Untuk kamera, kita bisa mempergunakan handycam. Bagi seorang pemula yang baru merintis usaha video shooting \& editing, menggunakan handycam sudah cukup diandalkan kualitas hasil produksinya. Harga handycam saat ini juga sudah sangat terjangkau sekitar kurang lebih 2 juta. Itu sudah cukup untuk merekam.

\section{b. Event Organizer}

Event organizer (EO) adalah jasa penyelenggaraan kegiatan dan merupakan usaha yang dilakukan untuk mempermudah rencana meyelenggarakan sebuah kegiatan atau event. Sebuah EO juga harus berani mengajukan sebuah ide baru yang kreatif dan berbeda. Jika itu bisa diterima 
oleh klien serta sukses, tentunya kemungkinan besar EO ini pun akan dipercaya untuk menggarap even-even berikutnya, dan bahkan even dari klien baru lainnya.

Kegiatan EO yang utama salah satunya adalah bagaimana mampu merumuskan konsep acara dan break down ke dalam kegiatan teknis yang sesuai untuk mencapai tujuan yang diharapkan oleh klien. Salah satu tahapan paling penting justru ketika hendak menentukan tema besar yang akan diangkat untuk sebuah event. Tema besar itulah yang nantinya akan dipecah menjadi agenda-agenda kecil yang saling terkait dan mendukung. Apabila tema besar yang diangkat cukup menarik.

Makin sukses sebuah event yang dibuat akan semakin dipercaya oleh klien untuk menangani berbagai event lainnya. Jika sudah punya beberapa portofolio event, EO bisa ikut pitching untuk beberapa proyek yang biasanya diselenggarakan oleh lembaga pemerintah atau berbagai perusahaan swasta. Lalu syarat apa saja yang diperlukan untuk suksesnya sebuah event organizer hingga mencapai suatu tahap memiliki branding image ternama? Berikut ini adalah syarat-syarat yang harus dimiliki sebuah event organizer.

Pertama, tetapkan pasar atau market bisnis yang akan dituju. Sebagai EO pemula atau yang akan memulai sebaiknya tentukan kemana EO akan dibawa, ke spesialis atau ke umum, tapi yang pemula lebih bagus ke spesialisasi dulu seperti konser musik, otomotif, expo atau pameran, wedding ceremony, atau seminar dan berbagai kegiatan perusahaan atau organisasi (launching, munas, rakernas dll). Dan seiring berkembangnya perusahaan, EO bisa mengembangkan ke pasar yang lebih luas.

Kedua, ide kreatif dan inovatif. Bisnis EO adalah bisnis komunikasi dan bisnis hiburan, kepuasan dan ketertarikan menjadi sangat penting untuk diperhatikan. Ketika tidak ada ide cemerlang dan kreatifitas, siap-siap gigit jari. Jangan takut untuk mewujudkan ide gila yang inovatif tapi bisa diterima masyarakat. Sebisa mungkin, hindari penawaran ide yang monoton. Usahakan munculkan ide tema acara yang menarik dan berbeda.

Ketiga, perlu punya database. Dalam mengelola bisnis EO, database mempunyai peranan yang amat penting. Baik itu database sponsor, media, lembaga pemerintah, mitra strategis, dan database klien itu sendiri. Database ini akan sangat membantu terutama saat kita mendapatkan proyek yang harus disiapkan dalam hitungan hari. Hal ini bisa saja terjadi dalam dunia EO. Karena kesibukan klien, mereka sering kali memberikan order secara mendadak, dan mau tidak mau EO harus bisa memberikan jasa yang terbaik dalam tenggat waktu yang cukup ketat. Dalam praktiknya, bisnis ini memang membutuhkan kelincahan tingkat tinggi dan jaringan yang luas. EO juga perlu bekerja sama dengan para pihak yang menyewakan segala perlengkapan yang biasanya dibutuhkan dalam sebuah event seperti sound system, LCD proyektor dan sebagainya. Hubungan dengan perusahaan percetakan atau advertising juga harus dibangun untuk mendapatkan supply bahan promosi dengan harga yang bersaing. Sebaiknya kita tidak hanya mengandalkan dari satu buah percetakan saja. Akan lebih aman jika EO mempunyai beberapa supplier percetakan sehingga bisa membandingkan harga dan membagi order jika dikejar oleh tenggat waktu yang ketat.

Keempat, bentuk teamwork yang solid. Elemen yang menentukan juga maju tidaknya EO, pilih beberapa orang yang punya kemampuan dibidang masing-masing, jangan terlalu banyak atau gemuk teamworknya, sedikit tapi punya kemampuan manajerial dalam memajukan EO, tapi akan bisa ditambah atau kita sesuaikan dengan situasu kondisi, misal ada sebuah event dan membutuhkan tenaga tambahan kita cari tenaga tambahan yg part time bersifat, dengan begitu kita mengefisiensikan anggaran.

Kelima, kemampuan menjual. Kemampuan menjual sebuah acara juga penting bagi seorang EO. Disamping untuk menggaet sponsor potensial, juga untuk bisa meraih target audience yang dibidik. Para calon sponsor potensial ini biasanya tidak akan ragu ragu untuk mendanai jika mereka melihat ada value lebih dari event yang kita selenggarakan. Bukan tidak mungkin, seorang sponsor akan membooking berbagai event yang akan kita selenggarakan sebagai wahana mereka berpromosi. Entah itu sebagai sponsor tetap atau bahkan menjadi sponsor tunggal dengan mendanai seluruh biaya event yang kita butuhkan. Sekali lagi, hal itu amat 
tergantung dari kemampuan kita menjual konsep dan meyakinkan mereka bahwa event yang kita selenggarakan sangat worth it bagi perusahaan mereka.

Keenam, berpikir detail. Tantangan lain seorang EO adalah bagaimana mampu melihat hal hal yang sangat detil dalam sebuah acara. Mulai dari teknis acara sampai perlengkapan yang sering kali jenisnya macam-macam. Seorang EO perlu membuat run down acara yang berisi teknis acara dan semua hal yang diperlukan selama acara tersebut. Dalam run down tersebut, akan bisa diketahui skenario acara dari detik ke detik berikut segala perlengkapan yang dibutuhkan. Seorang EO perlu memastikan ketersediaan seluruh perlengkapan yang dibutuhkan sebelum event dimulai. Tidak hanya itu saja, seluruh perlengkapan tersebut harus ditest terlebih dahulu sehingga bisa berfungsi secara optimal. Dalam hal tata letak panggung atau back drop, seorang EO perlu memperhatikan tinggi ruangan. Hal ini berkaitan dengan ukuran dan desain backdrop agar tampak lebih eye catching. Jika diperlukan, sebuah mini garden bisa dibuat, dan dipercantik dengan teknologi variasi sinar lampu yang bisa memperindah penampilan panggung. Jika tidak ingin repot, sebetulnya semua jasa pembuatan panggung atau backdrop ini bisa di serahkan kepada pihak lain yang profesional, tentu saja dengan imbalan atau fee yang telah disepakati.

Ketujuh, pembagian job description yang jelas. Hal ini juga sangat penting agar progres setiap event berjalan dengan baik dan hasil yang kita harapkan sesuai dengan konsep yang disepakati. Jadi menjelang ada event sudah kita bagi job description masing-masing dan harus melaporkan progresnya masing-masing pada setiap meeting. Hal ini untuk mengetahui tingkat kesiapan setiap event, karena sukses tidaknya suatu event sangat bergantung dengan kesiapan, koordinasi dan kerjasama antar teamwork.

Kedelapan, buat schedule atau jadwal kegiatan untuk satu tahun ke depan. Karena EO sudah menuju profesional jadwal kegiatan harus sudah ada untuk setahun ke depan karena inilah faktor utama mendapatkan hasil atau profit. Agar masyarakat tidak jemu kemas kegiatan dan buat berbeda tiap bulan.
Kesepuluh, modal usaha event organizer yang cukup. Untuk bisnis EO, perlu menyiapkan modal finansial terutama untuk memenuhi keperluan-keperluan EO seperti, Mengurus legalitas usaha (CV atau PT), menyewa kantor, pengadaan alat-alat kantor.

Kesebelas, ikuti wadah organisasi. Karena dengan adanya wadah organisasi/asosiasi EO sangat membantu perkembangan perusahaan. EO dapat berbagi pengalaman dan saling bertukar pengalaman dan saling membantu baik itu informasi atau dalam bentuk lainnya. Sekali lagi, yang penting dalam bisnis ini adalah kreativitas. EO pada dasarnya berjualan kreativitas. Hal-hal yang berbau kreativitas inilah yang bisa bernilai tinggi. Untuk itulah seorang klien yang merasa puas mau membayar mahal.

\section{HASIL DAN PEMBAHASAN}

\section{A. HASIL PELATIHAN}

Berdasarkan hasil observasi selama berlangsungnya kegiatan pelatihan, dapat disimpulkan bahwa kegiatan pelatihan bisa berlangsung secara efektif. Itu bisa dilihat dari peserta yang sangat serius dan antusias mengikuti jalannya pelatihan dan berusaha mempraktikkan apa yang telah disampaikan narasumber. Lebih dari itu, selama pelatihan terjalin komunikasi yang interaktif, didukung oleh suasana yang kondusif, sehingga peserta dapat menguasai materi pelatihan dengan baik.

\section{B. PEMBAHASAN}

Berdasarkan hasil pelaksanaan kegiatan pelatihan, maka dapat disimpulkan dua faktor penting yaitu faktor penunjang dan faktor penghambat. Faktor penunjang antara lain minat dan atusiasme peserta yang tinggi, serta tersedianya tempat pelatihan yang kondusif meski dari sisi kelengkapan sangat terbatas. Selain itu kegiatan ini juga mendapat respons dan dukungan dari segenap stakeholders desa.

Adapun faktor penghambat yang utama adalah jumlah Notebook dan piranti edit video shooting yang terbatas. Oleh karena itu kegiatan ini tidak dapat dilakukan secara optimal, dalam arti dapat menggunakan sarana pendukung yang lebih lengkap, di samping tentunya keterbatasan 
anggaran. Selanjutnya hambatan dari sisi waktu, karena kegiatan ini dilakukan pada hari kerja, maka peserta berusaha membagi waktunya, agar selepas pelatihan bisa meneruskan pekerjaannya.

\section{KESIMPULAN}

Berdasarkan uraian-uraian paragraf sebelumnya, serta berdasarkan observasi selama kegiatan dapat disimpulkan bahwa hasil kegiatan pengabdian masyarakat Pelatihan Berwirausaha Edit Video Shooting dan Event Organizer Bagi TKI Purna di Desa Cibolang, Kecamatan Gunung Guruh, Kabupaten Sukabumi ini adalah para TKI Purna memiliki kemampuan literasi keuangan sebagai bekal mereka berwirausaha. Selanjutnya, para TKI Purna sudah terampil mengoperasikan program editing video shooting sehingga bisa menjadi dasar membuka usaha di bidang tersebut. Selain itu, para TKI Purna juga mampu menjadi pelaku sekaligus membuka usaha di bidang event organizer.

Berdasarkan hasil observasi selama berlangsungnya kegiatan pelatihan, juga dapat disimpulkan bahwa kegiatan pelatihan bisa berlangsung secara efektif. Itu bisa dilihat dari peserta yang sangat serius dan antusias mengikuti jalannya pelatihan dan berusaha mempraktikkan apa yang telah disampaikan narasumber. Lebih dari itu, selama pelatihan terjalin komunikasi yang interaktif, didukung oleh suasana yang kondusif, sehingga peserta dapat menguasai materi pelatihan dengan baik. Hal yang lebih menggembirakan lagi adalah sudah terbinanya hubungan yang baik antara para TKI Purna di Desa Cibolang, Kecamatan Gunung Guruh, Kabupaten Sukabumi Jawa Barat dengan Universitas Negeri Jakarta.

Diharapkan kegiatan ini terus dilanjutkan, sehingga dampak positifnya bisa dinikmati oleh para TKI Purna di Desa Cibolang, Kecamatan Gunung Guruh, Kabupaten Sukabumi Jawa Barat. Lebih dari itu, ke depan, diharapkan Desa Cibolang, Kecamatan Gunung Guruh, Kabupaten Sukabumi Jawa Barat, bisa menjadi desa binaan Universitas Negeri Jakarta, sehingga program pengabdian sejenis bisa lebih dipersiapkan secara matang, lebih memberi dampak positif kepada para TKI Purna, yang muaranya adalah peran Universitas Negeri Jakarta lebih nyata dan bermanfaat bagi masyarakat Desa Cibolang, Kecamatan Gunung Guruh, Kabupaten Sukabumi Jawa Barat.

\section{DAFTAR PUTAKA}

Agus Wibowo. 2011. Pendidikan kewirausahaan: konsep dan strategi implementasi. Yogyakarta: Pustaka Pelajar.

. 2015. "Investasi Pendidikan dan Bonus Demografi." Media Indonesia, Edisi Senin, 18 Mei. . 2015. "Ekonomi Kreatif Entaskan Pengangguran." Koran Jakarta, Edisi Rabu, 4 Maret.

Dedi Purwana E.S. 2011. Menjadi Wirausaha Sukses. Bandung: Rosda Karya

Husaini Usman. 2006. Manajemen, teori, praktek dan riset pendidikan. Jakarta: Bumi Aksara.

Kementrian Pendidikan Nasional. 2010. Pengembangan Pendidikan Budaya dan Karakter Bangsa. Bahan Pelatihan Penguatan Metodologi Pembelajaran Berdasarkan Nilai-nilai Budaya Untuk Membentuk Daya Saing dan Karakter Bangsa. Jakarta : Kementrian Pendidikan Nasional.

.2010. Buku Induk Pembangunan

Karakter. Jakarta : Kementrian Pendidikan Nasional.

.2011. Pedoman Pelaksanaan Pendidikan Karakter (Bedasarkan Pengalaman di Satuan Pendidikan Rintisan). Jakarta : Kementrian Pendidikan Nasional Badan Penelitian dan Pengembangan Pusat Kurikulum dan Perbukuan.

Nusron Wahid. 2015. BNP2TKI: TKI Purna

Kini Lebih Mudah Kembali Bekerja di Luar Negeri.http://bisniskeuangan.kompas.com/read/ 2015/11/30/164300526/BNP2TKI.TKI.Purna. Kini.Lebih.Mudah.Kembali.Bekerja.di.Luar. Negeri

Thomas W. Zimmereer and Norman M. Scarboroug. 2006. Essential of entrepreneurship and small business management, fourth edition. Pearson Prentice-Hall Inc. 
Sembilan daerah di Jabar jadi pemasok TKI terbanyak. Diakses tanggal 19 Februari 2016, Jam 07.15 WIB pada laman: http://nasional. republika.co.id/berita/nasional/pemprov-jabar/ 16/02/16/o2mvai365-sembilan-daerah-di-jabarjadi-pemasok-terbanyak-tki.

Penempatan TKI di Luar Negeri. Diakses tanggal 20 Februari 2016, Jam 09.15 WIB pada laman: http://www.bnp2tki.go.id/readfull/9801/ Sepanjang-2014-BNP2TKI-MencatatPenempatan-TKI-429.872-Orang.

Cegah TKI Bermasalah Di Sukabumi. Diakses tanggal 20 Februari 2016, Jam 09.15 WIB pada laman: http://www.beritasatu.com/ nasional/299359-cegah-tki-bermasalah-bnp2tkisosialisasi-di-kabupaten-sukabumi.html.

BNP2TKI Akan Latih 15.000 TKI Purna Jadi Wirausaha Baru. Diakses tanggal 21 Februari 2016, Jam 12.15 WIB pada laman: http://www.
bnp2tki.go.id/read/9982/BNP2TKI-Akan-Latih15.000-TKI-Purna-Jadi-Wirausaha-Baru.

Kiriman TKI Selama 2015, Rp 700 M Mengalir ke Kabupaten Sukabumi. Diakses tanggal 19 Februari 2016, Jam 12.15 WIB pada laman: http://jabar.pojoksatu.id/sukabumi/2016/ 01/06/kiriman-tki-selama-2015-rp-700-mmengalir-ke-kabupaten/.

TKI Asal Sukabumi Berpendidikan Rendah. Diakses tanggal 19 Februari 2016, Jam 12.15 WIB pada laman: http://www.pikiran-rakyat. com/jawa-barat/2015/05/29/329100/tki-asalsukabumi-berpendidikan-rendah.

Cegah TKI Bermasalah, BNP2TKI Sosialisasi di Kabupaten Sukabumi. Diakses tanggal 19 Februari 2016, Jam 12.15 WIB pada laman: http://www.bnp2tki.go.id/read/10414/CegahTKI-Bermasalah-BNP2TKI-Sosialisasi-di Kabupaten-Sukabumi.html 